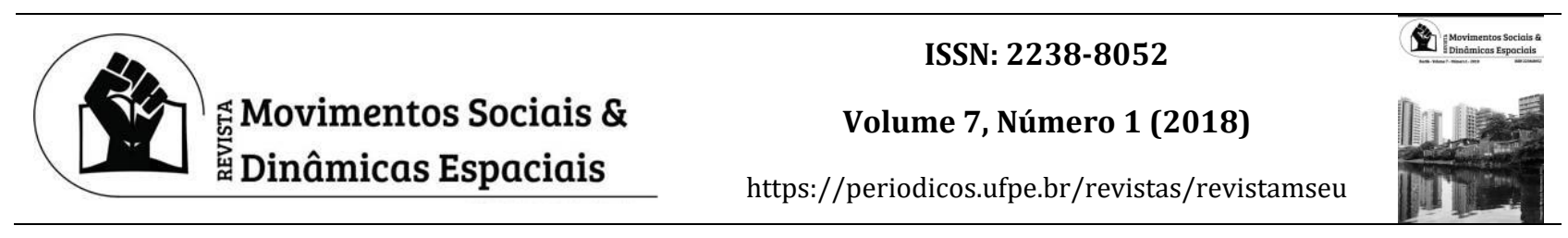

\title{
A EXPANSÃO URBANA DE GARANHUNS-PE ENTRE 1811 E 2016 E SUAS IMPLICAÇÕES SOCIOAMBIENTAIS
}

\author{
THE URBAN EXPANSION OF GARANHUNS BETWEEN 1811 AND 2016 AND ITS SOCIO- \\ ENVIRONMENTAL IMPLICATIONS
}

\author{
Antonio Benevides SOARES ${ }^{1}$ \\ Adriano Lima TROLEIS ${ }^{2}$
}

Artigo recebido em 11/06/2017 e aceito em 29/05/2018

Palavras-chave:

Expansão urbana;

Nascentes;

Garanhuns-PE.

Keywords:

Urban expansion;

Springs;

Garanhuns-PE.

\section{R E S U M O}

Ao longo de sua história a cidade de Garanhuns passou por processos dinamizadores da economia que intensificaram a expansão urbana e geraram diversas implicações socioambientais, especialmente nos recursos hídricos presentes no ambiente urbano. Diante disso, este artigo teve como objetivo analisar a expansão urbana de GaranhunsPE entre 1811 e 2016 considerando as implicações socioambientais desse processo em nascentes presentes no meio urbano. 0 estudo promoveu uma caracterização do meio físico com destaque aos aspectos relevantes ao processo de ocupação e a partir disso também caracterizou a expansão de Garanhuns com foco no uso e na ocupação no entorno das áreas de nascentes, produzindo assim, um mapa síntese dos diferentes períodos de evolução da mancha urbana de Garanhuns entre 1811 e 2016.

\begin{abstract}
A B S T R A C T
Throughout its history the city of Garanhuns has undergone transformative processes of the economy that intensified the urban expansion and generated diverse socioenvironmental implications, especially in the water resources present in the urban environment. Therefore, this paper had the objective of analyzing the urban expansion of Garanhuns-PE between 1811 and 2016, considering also the socioenvironmental implications of this process in springs present in the urban environment. The study promoted a characterization of the physical environment highlighting the aspects relevant to the process of occupation and urban expansion and from this also characterized the urban expansion of Garanhuns focusing on the use and occupation around the areas of springs in the urban environment, thus producing a Map of the different periods of evolution of the urban spot of Garanhuns between 1811 and 2016.
\end{abstract}

\footnotetext{
1 Técnico em Meio Ambiente, Licenciado e Especialista em Ensino de Geografia. Mestre em Geografia pela Universidade Federal do Rio Grande do Norte, Natal-RN, Brasil. E-mail: a-bene2011@hotmail.com.

2 Doutor em Geografia e Docente do Departamento de Geografia da Universidade Federal do Rio Grande do Norte (UFRN). Professor do Programa de Pós-Graduação em Geografia da UFRN. E-mail: adrianotroleis@gmail.com.
} 


\section{INTRODUÇÃO}

A partir da década de 1950, o Brasil embarcou numa expressiva urbanização que teve como característica o crescimento urbano majoritariamente desigual, mal planejado e poucas vezes executado nas raras vezes em que era planejado, trazendo uma série de problemas socioambientais, tais como condições precárias e insalubres de moradia e degradação de áreas de proteção ambiental. Essa lógica de expansão aconteceu de forma marcante nas diversas regiões brasileiras até mesmo em cidades do interior pernambucano das quais tomamos Garanhuns como foco de estudo deste artigo.

A localização geográfica estratégica com clima ameno e abundância de recursos hídricos foi fundamental para o surgimento da ocupação inicial do município de Garanhuns que teve a história de seu crescimento marcada por processos dinamizadores da economia que aceleraram vertiginosamente a expansão urbana. A chegada da linha férrea em 1887 foi um desses processos e desencadeou um vigoroso crescimento urbano fortalecido na década de 1950 pela construção de rodovias que propiciaram a transformação de Garanhuns em polo regional.

Com o crescimento do centro urbano garanhuense ocorrendo de forma rápida e majoritariamente desplanejada, diversos problemas socioambientais foram surgindo e se intensificando dentre eles destacam-se as condições precárias de moradia em áreas de risco, o aterramento e a poluição de nascentes. Tal situação foi se agravando e nos anos 2000 ganhou ainda mais força devido a uma expressiva expansão universitária e ao crescimento do setor de serviços.

Diante do exposto, definiu-se como objetivo geral deste artigo analisar a expansão urbana de Garanhuns-PE e suas implicações socioambientais tendo como horizonte temporal de 1811 até 2016. Para alcançar tal objetivo, definiram-se os seguintes objetivos específicos:

- Caracterizar o meio físico e seus aspectos relevantes à ocupação e expansão urbana;

- Caracterizar a expansão urbana de Garanhuns com foco no uso e na ocupação no entorno das áreas de nascentes;

- Produzir um mapa que sintetize diferentes períodos da evolução da mancha urbana de Garanhuns entre 1811 e 2016.

Dentro das implicações ambientais da expansão urbana daremos ênfase ao impacto nas nascentes presentes no meio urbano, tal escolha analítica se deu em razão da importância histórica e ambiental dessas nascentes, sendo fundamentais no estabelecimento e no desenvolvimento do núcleo urbano inicial, bem como para o abastecimento da cidade durante mais de quarenta anos. Além disso, as referidas nascentes pertencem à bacia do Rio Mundaú e a realização do estudo proposto remete-se à necessidade de contribuir com o cumprimento do Plano Diretor de Garanhuns no tocante à produção de análises, diagnósticos e produtos cartográficos que subsidiem a proteção das Áreas de Preservação Permanente (APP) e que contribuam com a efetivação de outros instrumentos de proteção e 
recuperação ambiental das nascentes propostos no Plano Diretor em vigor e que até o momento não foram realizados pelo poder público.

\section{MATERIAL E MÉTODOS}

Para operacionalizar a pesquisa em consonância com os objetivos propostos, foram necessárias algumas etapas especialmente no que concerne a confecção de material cartográfico para subsidiar a análise do processo de expansão urbana.

Para a confecção de mapas foram adquiridos materiais cartográficos (imagens de satélite e arquivos vetoriais) na Companhia Pernambucana de Saneamento (COMPESA), na Secretaria de Planejamento de Garanhuns, bem como nos sites do IBGE, Instituto Nacional de Pesquisas Espaciais (INPE) e Companhia de Pesquisa de Recursos Minerais (CPRM).

Os softwares utilizados para a elaboração dos planos de informação, editoração e acabamento dos mapas foram: ArcGIS 10.1, Google Earth e Photoshop CS5.

Para confeccionar o mapa de localização foram utilizados arquivos vetoriais em formato shapefile referentes aos limites da América do Sul, dos estados brasileiros e dos municípios de Pernambuco adquiridos no site do IBGE. Também foi usada uma imagem do satélite DigitalGlobe adquirida no Google Earth e georreferenciada no ArcGIS 10.1 adicionado pontos de controle. Após o georreferenciamento foi criado um arquivo vetorial correspondente aos limites do núcleo urbano do distrito sede de Garanhuns. Já os pontos correspondentes à localização das nascentes foram obtidos em campo utilizando um aparelho GPS (Global Positioning System) portátil da Garmin modelo eTrex 10.

Para a confecção do mapa de solos foram utilizados arquivos vetoriais em formato shapefile fornecidos pelo IBGE e pela EMBRAPA referentes aos limites dos municípios e do Zoneamento Agroecológico de Pernambuco referente às classes de solos. Também foi usado o arquivo vetorial referente aos limites da malha urbana do distrito sede de Garanhuns. Para o mapa das unidades litógicas presentes em Garanhuns foram usados os mesmos dados do mapa de solos, com excessão dos dados da EMBRAPA, que foram substituídos pelos das unidades litógicas fornecidos pelo geobank da CPRM.

O mapa hipsométrico de Garanhuns com classes de altitude de 50 metros foi gerado a partir da obtenção de curvas de nível com espaçamento de 10 metros obtidas utilizando o ArcGIS 10.1, através de dados Shuttle Radar Topography Mission (SRTM) obtidos no site do INPE (Projeto Topodata) em formato geotiff com resolução espacial de 30 metros. Também foram usados dados dos limites do município e do núcleo urbano já mencionados anteriormente. 
O mapa da rede de drenagem de Garanhuns foi gerado no ArcGIS 10.1 através da ferramenta hidrology usando dos mesmos dados SRTM do mapa hipsométrico. A partir desses dados foi gerado o relevo sombreado do terreno e a drenagem com os cursos d'água. Nesse mapa também foram utilizados os planos de informação dos limites do município, núcleo urbano e da localização das nascentes.

Para o mapa de expansão urbana de Garanhuns entre 1811 e 2016, foram criados quatro arquivos vetoriais sendo dois deles elaborados a partir de croquis feitos por Sette (1956), assim foi possível saber os limites do núcleo urbano em 1811 e 1887 com precisão, pois as vias não se alteraram. Para os limites do núcleo urbano dos anos de 1965 e 1982 foram utilizadas ortofotos retiradas de Azambuja (2007). Para o ano de 2016, os limites do núcleo urbano foram obtidos pela imagem do DigitalGlobe obtida no Google Earth. Já para os limites dos loteamentos que estão sendo implantados e das áreas para expansão futura, foi feita análise da imagem do DigitalGlobe que contém demarcações dos novos loteamentos. Além disso, realizaram-se pesquisas de solicitações de aprovação de loteamentos na prefeitura, bem como idas a campo para identificar loteamentos e ocupações iniciados recentemente. Todos esses planos, juntamente com a localização das nascentes, foram sobrepostos com efeitos de transparência sobre a imagem do DigitalGlobe.

\section{RESULTADOS E DISCUSSÃO}

\subsection{CARACTERIZAÇÃo DA ÁREA DE ESTUDO}

Neste tópico, será feita a caracterização do meio físico de Garanhuns a partir dos fatores que são determinantes na formação e diferenciação das nascentes bem como na forma como o núcleo urbano se expandiu. Dessa forma, a caracterização envolverá a contextualização dos aspectos geomorfológicos, geológicos, climatológicos e hidrológicos relevantes ao estudo, pois o clima, os tipos de solos, de relevo e de substrato rochoso são extremamente importantes para uma avaliação das fragilidades e/ou potencialidades da área de estudo no que diz respeito aos impactos socioambientais. A caracterização do meio físico também é essencial para mostrar a singularidade e a importância dos aspectos físico-naturais do município no processo de ocupação do sítio urbano que apresenta abundância em recursos hídricos em contraste com cidades próximas que vivem as dificuldades do semiárido. 


\subsubsection{Situação e localização geográfica da área de estudo}

A área de estudo situa-se no centro urbano do município de Garanhuns, que se localiza na Mesorregião Agreste e na Microrregião Garanhuns do estado de Pernambuco, entre as coordenadas geográficas $08^{\circ} 51^{\prime} 00^{\prime \prime} / 08^{\circ} 55^{\prime} 00^{\prime \prime}$ de latitude sul e $36^{\circ} 31^{\prime} 00^{\prime \prime} / 36^{\circ} 27^{\prime} 00^{\prime \prime}$ de longitude oeste (Fig. 01) distando cerca de $230 \mathrm{~km}$ de Recife (capital). Em termos populacionais, Garanhuns é o nono maior município do estado de Pernambuco, com uma população de 129.408 habitantes e segundo o censo de 2010 a estimativa para 2016 era de 137.810 habitantes (IBGE, 2016), sendo a maior parte residentes em áreas urbanas que compreendem os núcleos habitacionais dos distritos de São Pedro, Sede, Miracica e Iratama. De acordo com os dados do último censo (IBGE, 2010), Garanhuns possuía 89\% da população vivendo na zona urbana enquanto no estado de Pernambuco esse percentual era $80 \%$ e no Brasil de 84\%, o que, aliado ao saneamento precário 3 do município, traz graves problemas para os corpos hídricos urbanos.

Figura 01. Localização de Garanhuns.

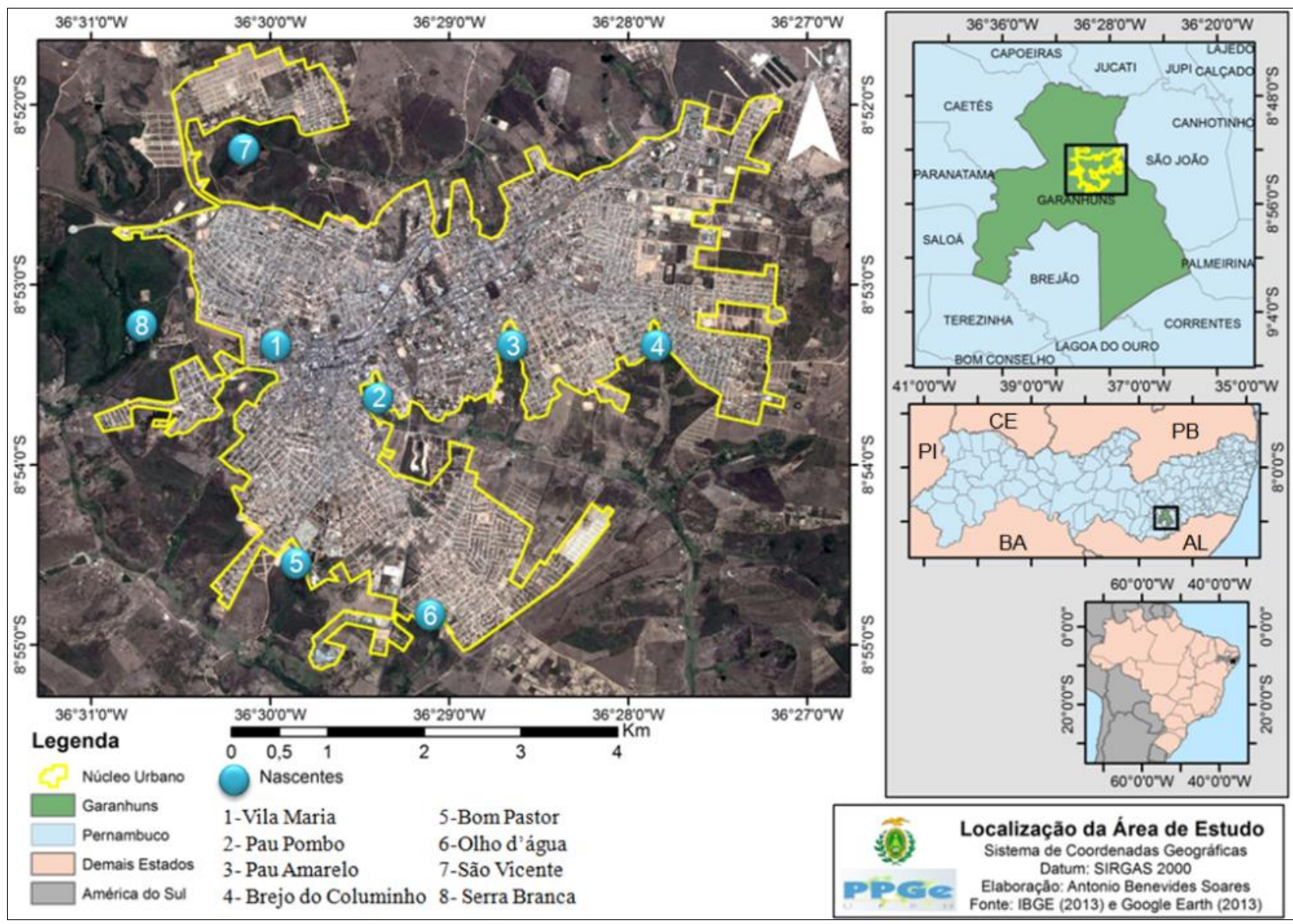

Fonte: Elaborado com base em dados do IBGE (2013) e Google (2013).

\footnotetext{
${ }^{3}$ Segundo a COMPESA somente $12 \%$ da cidade possui rede coletora de esgoto. Na pesquisa de campo percebeu-se que nos bairros as águas servidas são ligadas aos canais de águas pluviais e jogadas nos vales onde se localizam nascentes.
} 
Garanhuns tem importante papel como polo universitário e econômico, concentrando atividades industriais, comerciais, de saúde, educacionais e turísticas, sendo por isso o município mais influente da Região de Desenvolvimento Agreste Meridional (CONDEPE/FIDEM, 2014). Contribuiu para esse protagonismo regional o fato da cidade de Garanhuns ser centro de convergência de importantes rodovias federais (BR 423 e BR 424) e estaduais (PE 208 e PE 117), assim a cidade se apresenta como rota para as mais importantes regiões do Nordeste, oferecendo uma localização estratégica em relação a grandes centros, pois sete das nove capitais do nordeste ficam a um raio de $600 \mathrm{~km}$ de Garanhuns, sendo que três dessas capitais ficam a menos de $350 \mathrm{~km}$ do município. Nesse sentido, além dos fluxos internos ao estado, a cidade também recebe fluxos de diversos estados com destaque para Alagoas, Sergipe e Bahia,

Tais características têm contribuído para uma expansão urbana vigorosa apoiada numa economia que segue o padrão brasileiro e pernambucano com o setor de serviços tendo a maior participação no Produto Interno Bruto (PIB), seguido pela indústria e pela agropecuária, destaque-se que em Garanhuns o setor de serviços é tão forte que tem mais participação no PIB que a indústria e a agropecuária juntas.

O PIB do município é o $11^{\circ}$ do estado e $413^{\circ}$ do país, no entanto, no que refere ao desenvolvimento humano, o município ocupa a $16^{\text {a }}$ posição no estado e a $2802^{\mathrm{a}}$ em âmbito nacional com um Índice de Desenvolvimento Humano Municipal (IDHM) de 0,664 em 2010, resultado que é considerado médio, porém está abaixo da média nacional que é de 0,744 , índice que já é considerado elevado. Mesmo assim, Garanhuns possui resultado melhor que 49,67\% dos municípios do país e no período entre 1991 e 2010, teve um incremento no seu IDHM de 42,49\% (IBGE, 2013; PNUD, 2014). No entanto, ainda há precariedade e pobreza, principalmente nas áreas periféricas da cidade, geralmente onde os bolsões de pobreza se concentram em áreas ambientalmente desfavoráveis à ocupação, como é o caso das moradias precárias no entorno de vales com vertentes íngremes.

\subsubsection{Aspectos geológicos, pedológicos e geomorfológicos}

Garanhuns localiza-se no planalto da Borborema, ao sul do Lineamento Pernambuco no Batólito Pernambuco-Alagoas. Tal como é possível observar na Figura 02, no município destaca-se o Complexo Belém de São Francisco sobre o qual a maior parte da área municipal se insere, porém, o núcleo urbano está localizado na quarta unidade do Complexo Cabrobó, onde predominam quartzitos que fazem parte do que se convencionou chamar de Unidade Quartzítica da Região de Garanhuns (CPRM, 2013). Segundo o Plano Diretor de Recursos Hídricos da Bacia do Rio Mundaú (PERNAMBUCO, 1999), a Unidade Quartzítica da Região de Garanhuns é uma componente litoestratigráfica que se constitui em uma unidade metassedimentar clástica composta de quartzitos, metarcósios e grauvacas 
que tem subjacente o Complexo Migmatítico-Granitoide onde há predominância de migmatitos, contudo também reúne rochas granitizadas e variados tipos texturais (PERNAMBUCO, 1999, p. 24).

Figura 02. Mapa dos solos e das unidades litológicas presentes em Garanhuns-PE.

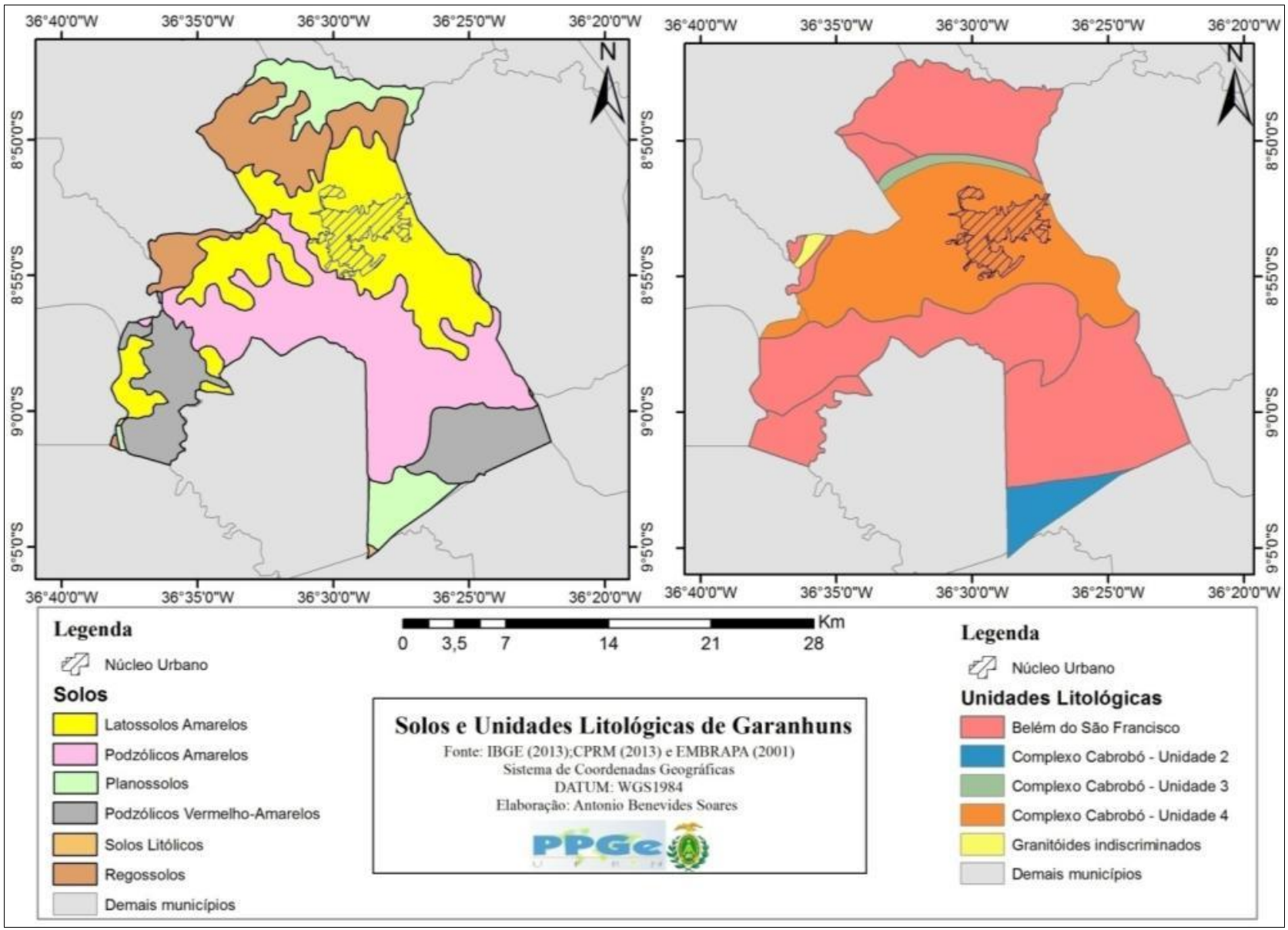

Fonte: Elaborado com base nos dados da EMBRAPA (2000), do IBGE (2013) e da CPRM (2013).

A Unidade Quartzítica da Região de Garanhuns apresenta-se em camadas sub-horizontais que chegam a alcançar 50m de espessura, possuindo acentuado grau de alteração com um espesso manto de intemperismo que "[...] desempenha importante papel como aqǘfero, sendo portador de água de qualidade mineral, fartamente explorada comercialmente" (PERNAMBUCO, 1998, p.151). 0 embasamento rochoso majoritariamente composto de quartzitos se constitui em bom aquífero quanto à qualidade da água, mas possui limitações quanto à potencialidade das vazões (PERNAMBUCO, 1998). Mesmo assim o município possui inúmeras nascentes perenes e poços de boa produtividade, tanto que Garanhuns é o mais antigo produtor de águas minerais de Pernambuco e já na década de 1950, a indústria extrativista de água mineral do município era a segunda maior do estado, ficando atrás apenas de Recife (IBGE, 1959). Na atualidade, ainda há exploração de águas subterrâneas por 
empresas locais fazendo com que Garanhuns permaneça entre os maiores produtores de águas minerais de Pernambuco.

Já na década de 1950, Dias (1954) destacava que as características geológicas de Garanhuns permitiam encontrar águas oligominerais e lítinadas ambas muito valorizadas para comercialização por possuírem propriedades terapêuticas. Diante disso, Dias (1954) chegou a acreditar que o futuro de Garanhuns era se tornar uma estância hidromineral, pois segundo o autor:

\begin{abstract}
A suas águas minerais são múltiplas e variadas, tal como: a litinada da Serra Branca, as magnesianas da $<<$ Vila Maria $>>$, do $<<$ Pau Amarelo $>>$, da Serra dos Fojos, a litinada da Serra do Brejão da Fazenda $<<$ Brasileiro $>>$, as de mesa do Cajueiro, da $<<$ Vila Regina $>>$, a do $<<$ A'rabe $>>$ e a do Sanatório $<<$ Tavares Correia $>>$, todas elas, situadas nos arredores da cidade, estão fadadas, pela sua potabilidade e importância medicinal, a darem à terra de Simôa Gomes o lugar de destaque a que faz jus, pelo esplendor do clima e riqueza mineral de seu solo (DIAS, 1954, p. 36).
\end{abstract}

No entanto, a previsão do autor não se concretizou, pois em razão da expansão urbana muitas das nascentes mencionadas por ele foram aterradas ou estão sofrendo graves danos ambientais, como é caso das nascentes Vila Maria, Pau Pombo e Pau Amarelo.

Na Unidade Quartzítica da Região de Garanhuns os principais solos desenvolvidos são: Latossolos Amarelos, Podzólicos Amarelos, Areias Quartzosas e Planossolos (EMBRAPA, 2000, p. 34). Porém, também há os solos formados a partir do Complexo Migmatítico-Granitóide representado litologicamente por rochas granitizadas com predominância de migmatitos, onde "Os principais solos desenvolvidos a partir das rochas deste Complexo, são: Brunos não Cálcicos, Planossolos, Solos Litólicos, Cambissolos, Regossolos e Podzólicos Vermelho-Amarelos" (EMBRAPA, 2000, p. 36). Para Azambuja (2007) pode-se dizer que os solos de Garanhuns têm duas origens, uma derivada do intemperismo dos quartzitos e outra do transporte e deposição, gerando solos alóctones. A autora destaca que há uma extrema complexidade entre perfis pedogenéticos e descontinuidades aloestratigráficas sob o sítio urbano de Garanhuns.

Na área de estudo, conforme mostra a Figura 02, há predominância de Latossolos Amarelos e a presença de Podzólicos Amarelos margeando o centro urbano, no entanto, na área urbana é possível verificar também a existência de Argissolos principalmente nos topos de paisagem juntamente com Latossolos, como bem destacou Azambuja (2007). Os Podzólicos Amarelos são solos profundos e na área de estudo apresentam um textura média/ argilosa. Segundo Ross (2010), esse tipo de solo possui grau de fragilidade médio à erodibilidade por escoamento superficial das águas pluviais. Já os Latossolos Amarelos e os Argissolos são solos profundos, bem drenados, apresentam boa retenção de umidade e permeabilidade, favorecendo o abastecimento dos aquíferos que alimentam as nascentes, porém também são susceptíveis à erosão hídrica, principalmente em encostas ocupadas inadequadamente por moradias (Fig. 03), algo comum em Garanhuns que, por essa razão, apresenta grandes voçorocas em várias partes do centro urbano, sendo tais processos erosivos responsáveis por aterramento de nascentes através da deposição de sedimentos na área de exfiltração. 
Figura 03- A: Mordias precárias em encosta íngreme no Vale da Liberdade onde se localiza a Nascente Pau Amarelo B: Erosão causada por canalização de águas pluviais realizada de forma inadequada na Nascente Bom Pastor.
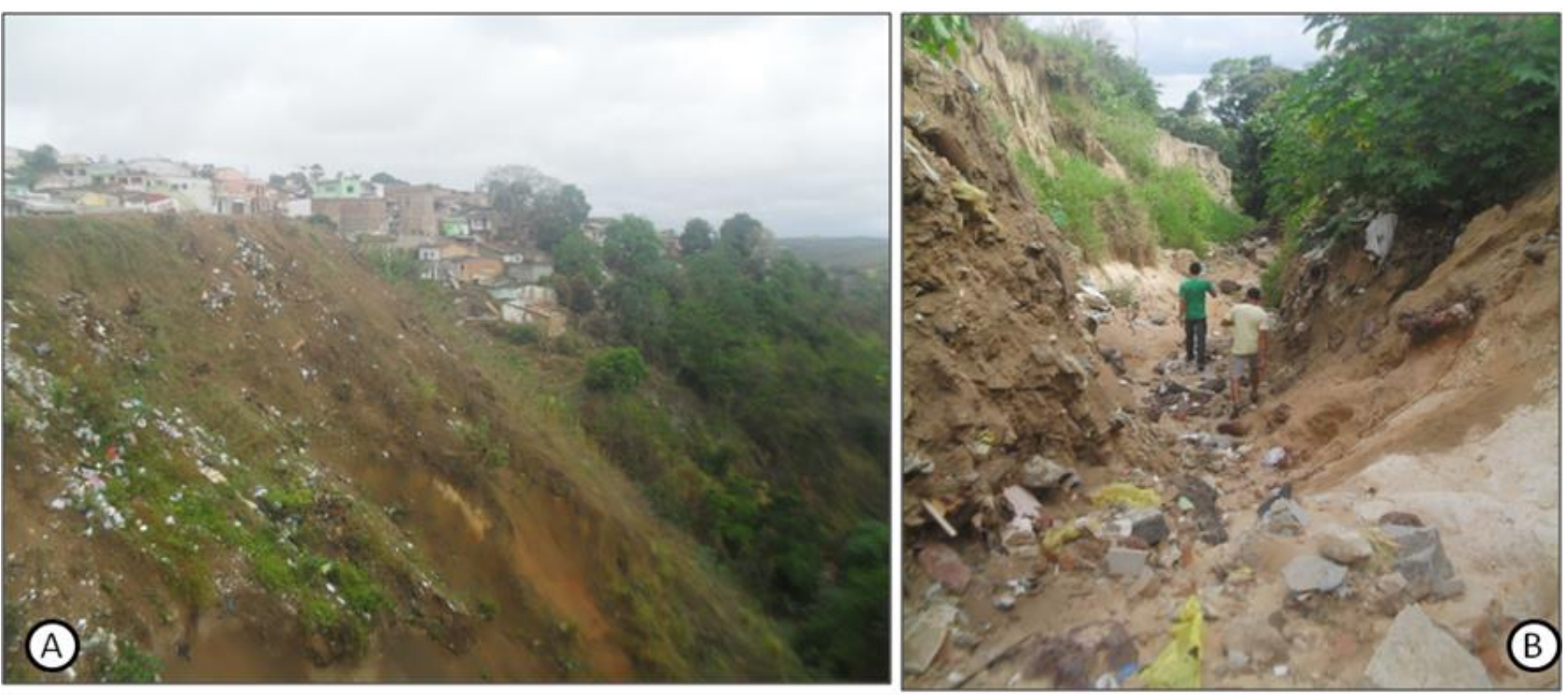

Fonte: Acervo do autor (2015).

O município de Garanhuns apresenta altitudes que variam entre 468 e 1030 metros. No centro urbano, as altitudes variam entre 750 e 1030 metros (Fig.04), sendo uma das partes mais altas do planalto denominado de patamar erosivo de Garanhuns que se constitui numa das superfícies mais elevadas da Borborema (CORRÊA et al, 2010). A maior parte do centro urbano de Garanhuns está entre 900 e 1000 metros de altitude sobre superfície somital tabular, porém também há superfícies somitais convexas que configuram os pontos mais altos da cidade, chegando a 1030 metros de altitude. Essas formas agem como dispersores de águas que são direcionadas para vales profundos onde se localizam a maioria das nascentes presentes na área de estudo e que dão origem a cursos d'água de primeira ordem perenes e intermitentes.

No centro urbano de Garanhuns estão presentes vertentes retilíneas, côncavas e convexas. Nas vertentes retilíneas predominam as cicatrizes de deslizamento, nas côncavas ocorre a convergência de águas, resultando na formação de voçorocas e nas vertentes convexas predominam erosão uniforme e laminar (AZAMBUJA, 2007). Esses tipos de vertente, associados à alta declividade e ao uso e ocupação inadequados do solo, aceleram os processos erosivos que ameaçam tanto as moradias próximas como as nascentes e, consequentemente, os córregos originados nelas. 
Figura 04. Mapa hipsométrico de Garanhuns-PE.

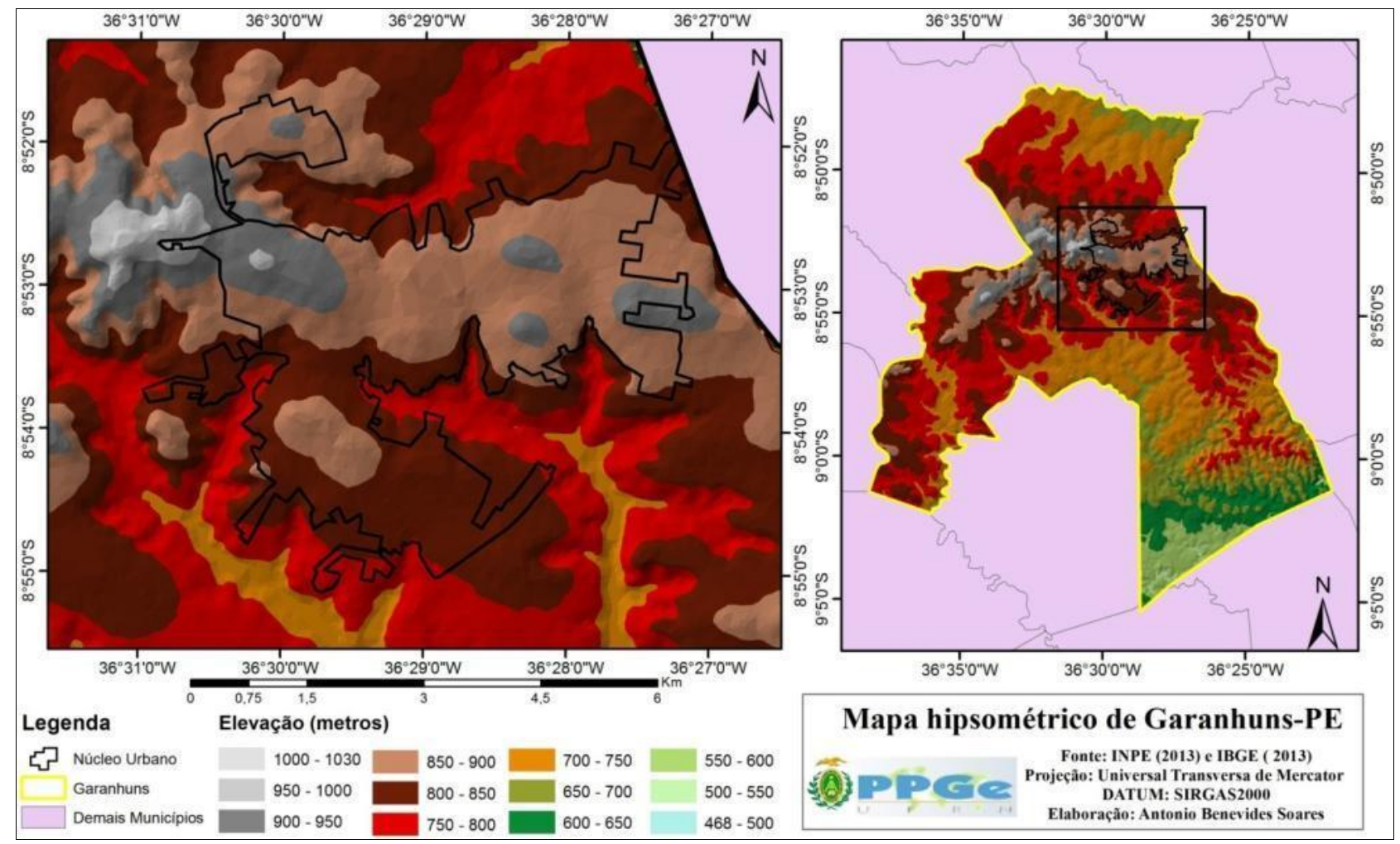

Fonte: Elaborado com base em dados do INPE (2013) e do IBGE (2013).

\subsubsection{Aspectos vegetacionais, climáticos e hidrológicos}

As altitudes elevadas e a proximidade da faixa de rebordo do Planalto da Borborema propiciaram a Garanhuns singularidades climáticas e florísticas em relação ao seu entorno devido ao efeito orográfico que propicia chuvas de relevo, assim, a maior parte da área do município se caracteriza como paisagem de exceção em relação ao seu entorno semiárido, pois em Garanhuns ocorrem brejos de altitude que são porções isoladas de floresta estacional semidecidual montana pertencente ao bioma Mata Atlântica (PORTO el al, 2004). Para Ab'Saber (1985, p. 15), os brejos são ilhas de umidade e de solos férteis, são um enclave de tropicalidade no meio semiárido. Os brejos de altitude ou de exposição são subespaços úmidos com vegetação e totais pluviométricos diferenciados de seu entorno, caracterizando-se por altitudes superiores a 600 metros com pouca deficiência hídrica e totais pluviométricos que variam de 900 a 1.300 mm anuais (LINS, 1989, p. 96). "É evidente que isso só ocorre em determinados sítios, como serras e encostas de maciços que captam a umidade de barlavento" (AB'SABER, 1985, p. 15). Segundo Ab'Saber (1985, p. 15), o agreste pernambucano se caracteriza por ser complexo com “[...] setores abrejados, ao lado de verdadeiros brejos, como é o caso da região de Garanhuns". 
Garanhuns é abundante em recursos hídricos e por todo o território do município há grande quantidade de nascentes que dão origem a uma vasta rede hídrica com padrão dendrítico. Na Figura 05, vê-se a rede de drenagem do território municipal com destaque para o centro urbano onde as nascentes existentes dão origem a vários cursos d'água que confluem na bacia do Rio Mundaú ao sul e na bacia do Rio Canhoto ao norte. Na parte norte da cidade a nascente São Vicente dá origem ao curso d'água de mesmo nome, sendo a única nascente mostrada no mapa que pertence à Bacia do Rio Canhoto, as demais nascentes pertencem à bacia hidrográfica do Rio Mundaú. Todas as nascentes destacadas na Figura 05 possuem fluxo de vazão perene mesmo em períodos de estiagens severas, por isso, ao longo do tempo, sempre tiveram importância tanto no abastecimento como para as indústrias e para a agricultura, no entanto, mais recentemente vêm sendo fortemente impactadas pelos efeitos da urbanização desordenada que desconsidera completamente a dinâmica desses sistemas ambientais.

Figura 05. Rede de drenagem de Garanhuns-PE.

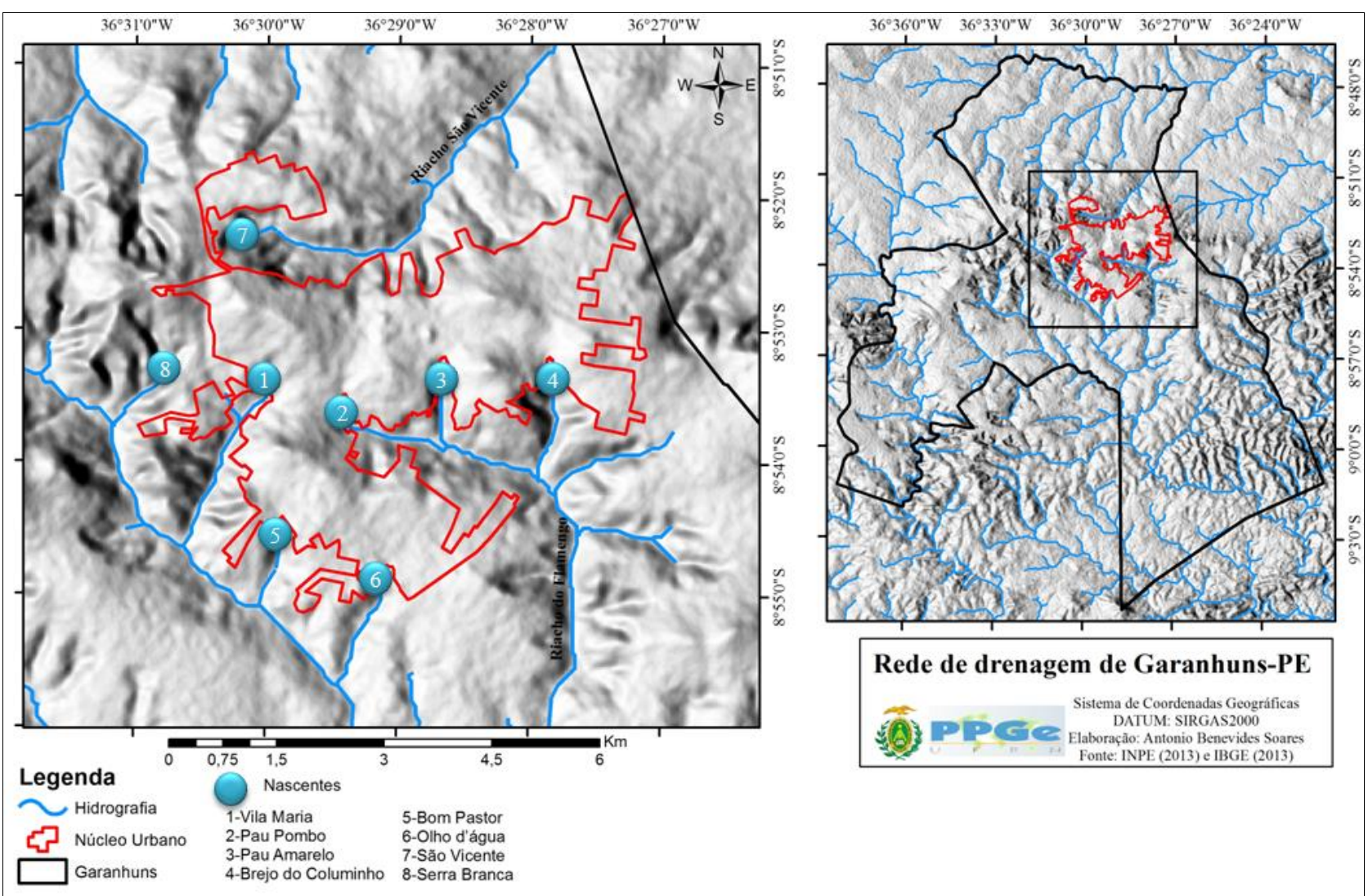

Fonte: Elaborado a partir de dados do INPE (2013).

No tocante aos aspectos climáticos, a área de estudo se apresenta como diferenciada na Região Nordeste e no estado de Pernambuco, pois devido à altitude elevada, o clima de Garanhuns é frequentemente descrito como tropical de altitude, o que corresponderia ao tipo Cw'a, de acordo com a classificação de Köppen-Geiger. Porém, segundo Jatobá (2004), Garanhuns possui clima mesotérmico 
com verões quentes e chuvas no outono e no inverno, apresentando características muitos semelhantes ao clima mediterrâneo tipo CS’a, conforme a classificação de Köppen-Geiger.

Conforme é possível observar na Figura 06, de acordo com a normal climatológica do período de 1961 até 1990, a temperatura mínima média anual em Garanhuns foi de 16,9º $\mathrm{C}$, a máxima média anual de $25,5^{\circ} \mathrm{C}$ e a média anual de 20,5ํㅡ. Nesse período, o município registrou uma precipitação anual média de $870,3 \mathrm{~mm}$, que são totais pluviométricos considerados altos em relação às áreas semiáridas circundantes e também são fundamentais para a recarga dos aquíferos que abastecem as nascentes existentes no município. Segundo Azambuja (2007, p. 63), além da Influência da Zona de Convergência Intertropical, esses totais pluviométricos ocorrem devido ao fato de Garanhuns se localizar próximo ao rebordo meridional da Borborema, o que permite a entrada da Frente Polar Atlântica e das perturbações das Ondas de Leste no outono.

Figura 06. Totais pluviométricos e temperaturas mínimas e máximas mensais.

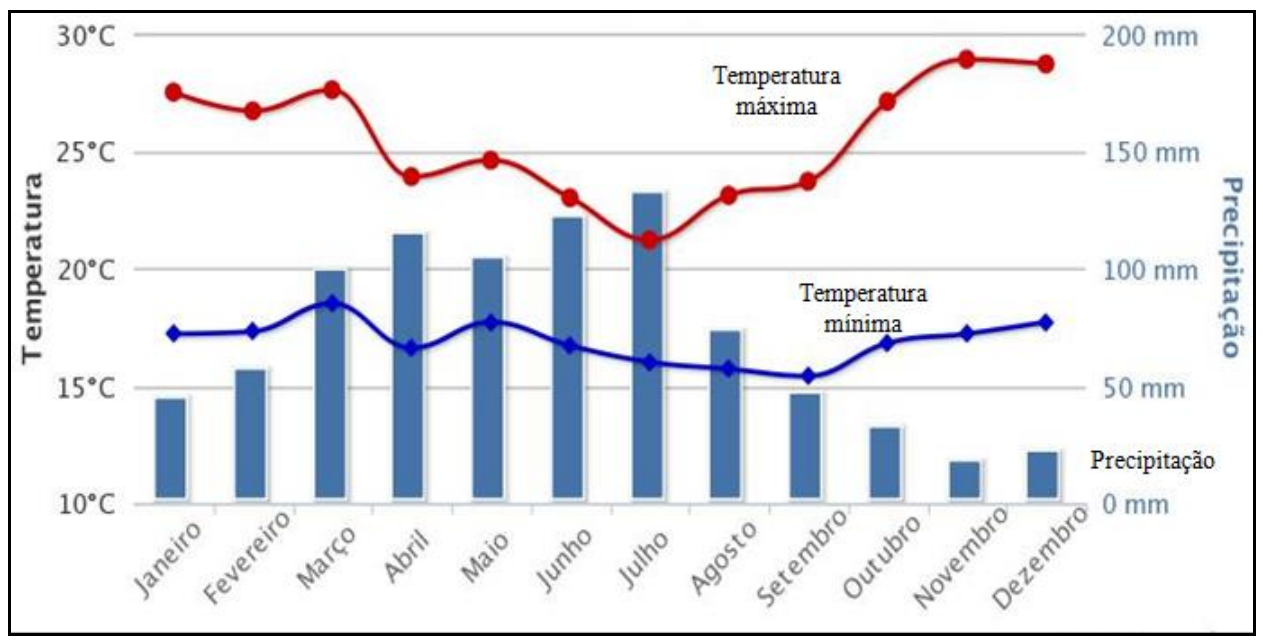

Fonte: Jornal do Tempo (2013).

Quanto à disponibilidade hídrica, os dados do trabalho de Andrade et al (2008, p. 59), gerados a partir da média mensal da série histórica de 1913 a 1987 (Figura 07), mostram que os meses mais chuvosos são maio, junho e julho e os mais secos outubro, novembro e dezembro. De acordo com dados da normal climatológica de 1961 a 1990, na Figura 07 observa-se que de setembro a fevereiro há déficit hídrico com destaque para o mês de dezembro em que há menos disponibilidade de água no solo (SENTELHAS; ANGELOCCI, 2009). Por outro lado, de março até agosto, ocorre reposição da água perdida nos meses secos e superávit hídrico com pico de grande disponibilidade hídrica no mês de julho, assim, de acordo com esses dados, há superávit hídrico em três meses e condições favoráveis em metade do ano ao abastecimento dos aquíferos que mantêm a vazão das nascentes presentes no centro urbano. 
Figura 07. A: Meses secos e chuvosos; B: Balanço hídrico (1961 a 1990).
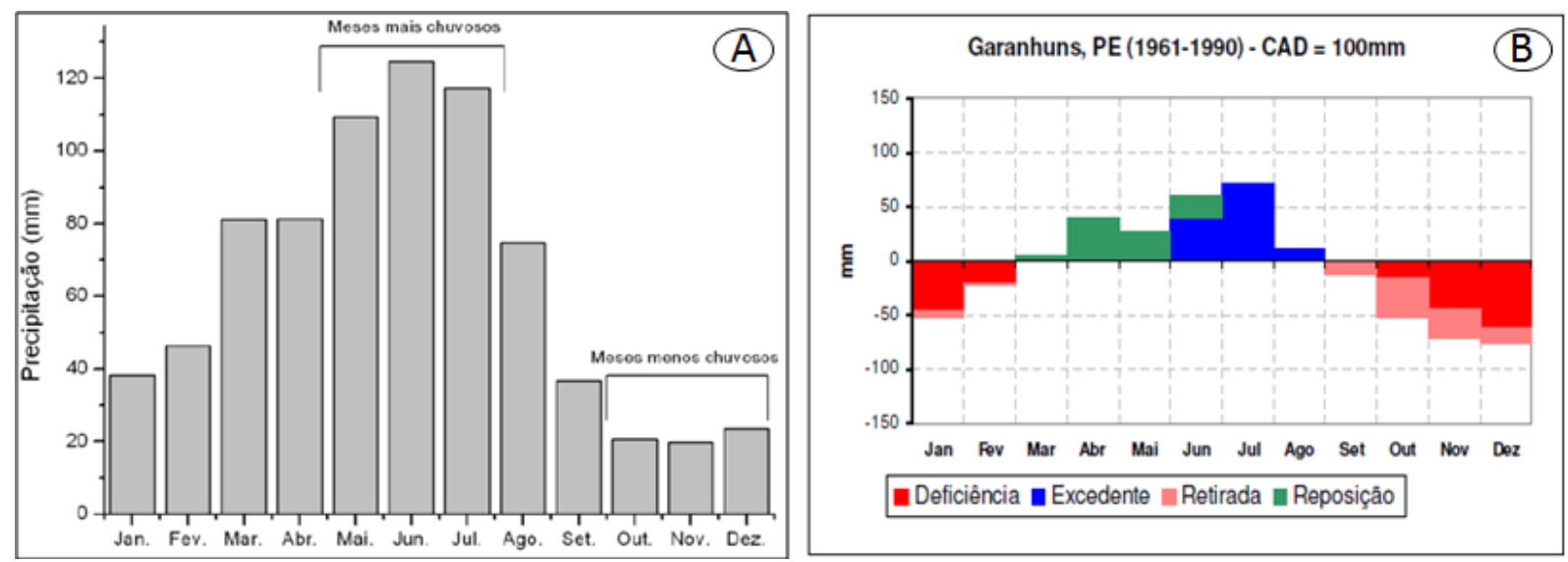

Fonte: A - Andrade et al (2008); B - Sentelhas e Angelocci (2009).

\subsection{Origem e expansão urbana de Garanhuns}

A distância do Planalto de Garanhuns até o mar, a altitude acima de 900 metros e a densa vegetação de mata existente foram aspectos que durante muito tempo dificultaram a ocupação humana na região onde atualmente a cidade de Garanhuns se localiza (SETTE, 1956). Essa fase de dificuldades em ocupar a região, começou a ser vencida a partir do momento em que os colonizadores perceberam nas características ambientais da capitania de Pernambuco diferentes formas de produzir resultando em distintas formas de ocupação e produção do/no espaço. Assim, na zona da mata, com maiores totais pluviométricos, decidiu-se produzir cana-de-açúcar para exportação, enquanto no sertão optou-se pela criação de gado voltada para consumo interno e agricultura de subsistência. Dessa forma, na medida em que o gado avançava para o interior, pequenas vilas e povoados foram surgindo, no entanto, o agreste mesmo sendo uma porção intermediária entre mata e sertão, só foi ocupado mais densamente após o sertão, o que, conforme Sette $(1956)^{4}$, pode ser explicado pelo obstáculo que a Borborema representou para o progresso do gado que seguiu avançando, em sua maioria, pelas margens do Rio São Francisco.

Outro fator considerável para a ocupação da região onde Garanhuns se localiza foi a penetração de escravos que fugiam dos grandes engenhos, Sette (1956) destaca que a guerra do açúcar acabou por enfraquecer os engenhos, permitindo fugas de escravos que acabaram se reunindo em quilombos nos "contrafortes orientais da Borborema", principalmente na Serra da Barriga, onde formou-se o Quilombo dos Palmares. Em razão dos constantes saques às fazendas, vilas e povoados, esses quilombos se tornaram um grande incômodo que só diminuiu com a derrota do Quilombo dos Palmares, após longa luta comandada pelo bandeirante Domingos Jorge Velho que, como prêmio pela

\footnotetext{
${ }^{4} \mathrm{O}$ geógrafo Manuel Correia de Andrade também defendeu esse ponto de vista em várias de suas obras.
} 
vitória contra os palmarinos, solicitou a Dom Pedro II, e recebeu as terras nas quais se incluía o Planalto de Garanhuns (DIAS, 1954, p. 105).

O sítio urbano de Garanhuns tem origem a partir da ocupação dessas terras por Miguel Coelho Gomes, que era filho de Domingos Jorge Velho e que se uniu a uma índia Unhanhú, estabelecendo uma fazenda com o nome de Sítio do Garcia na localidade Brejo do Coelho, posteriormente conhecida como Brejo das Flores, localizada na encosta do morro da Boa Vista (SETTE, 1956; DIAS,1954). De acordo com Sette (1956, p. 38), "Garanhuns teve semente plantada na meia encosta de um vale tributário do Rio Mundaú, justamente no lado exposto aos ventos frios vindos do quadrante sul e onde não se observa qualquer vestígio de terraço fluvial ou 'replat' que pudesse justificar a posição do sítio". Para o autor a ocupação nessa parte da encosta se deu pela dificuldade de obtenção de água nos topos e do excesso de umidade e das inundações no fundo do vale. Assim,

Na impossibilidade de ocupar tanto os níveis mais altos como os mais baixos do relevo local, devido à tirania da água, ali em carência e aqui em demasia, tiveram os primeiros povoadores de Garanhuns de se acomodar, em difícil posição de equilíbrio, no declive da encosta, a um só tempo livres do perigo de inundações e insalubridade e bem próximos às fontes cristalinas que devolvem ao fundo dos vales toda a água absorvida no teto das elevações (SETTE, 1956, p. 39).

Simôa Gomes, filha de Miguel Coelho Gomes, após ficar viúva, doou as terras onde hoje se localiza o centro da cidade para a Irmandade das Almas da Igreja de Santo Antônio. Nessas terras surgiram as primeiras residências do centro urbano e foi nelas onde a cidade nasceu perto das nascentes fundamentais ao abastecimento dos moradores, à criação de gado e à agricultura. No entanto, isso não representou inicialmente uma rápida expansão urbana, pois assim como Cavalcanti (1983), Sette (1956) destaca que Garanhuns permaneceu como um pequeno vilarejo apesar do rápido progresso nos campos político, administrativo e eclesiástico, onde já era sede de vicariato em 1796 e em 1811 havia sido elevada a categoria de vila com instalação solene dois anos mais tarde.

Segundo o IBGE (1959), em 1811, Garanhuns contava com 15.795 habitantes, porém poucos residiam onde hoje é a sede municipal, uma vez que nessa época o território de Garanhuns era muito maior que atualmente, tendo em vista que abrangia vilarejos que hoje são municípios e não pertencem mais a Garanhuns. Nessa época, o quantitativo populacional era distribuído em um território muito mais vasto e predominantemente rural. Assim, o aglomerado humano permaneceu com características típicas de habitat rural, servindo em muitos casos apenas como moradia temporária dos camponeses dos arredores. Em obra de 1844, Gama (apud SETTE, 1956, p. 41) afirma que quase todos os 44.265 habitantes da Freguesia de Garanhuns são agricultores. Por isso, "O crescimento do povoado em número de casas e em área ocupada arrastou-se lento, refletindo melhor as suas funções rurais que as urbanas". Em 1879, a Lei Provincial no 1.309, apresentada pelo deputado Silvino Guilherme de Barros (Barão de Nazaré), elevou Garanhuns a categoria de cidade. Segundo mostra Cavalcanti (1983, p. 194), o Barão de Nazaré, após visita a Garanhuns, viu grandes potencialidades na vila, especialmente como 
estação de repouso pelo clima singular e pelas águas minerais das nascentes próximas à cidade que, “[...] a despeito dos maiores verões, nunca secam". Por volta do século XVIII e do começo do século XIX, Garanhuns se constituía apenas em um arruado no entorno de uma igreja, essa situação só começou a mudar em 1887, com a chegada da linha férrea que trouxe maior fluidez tanto de mercadorias como de pessoas.

A chegada da ferrovia permitiu o aumento da produção e o escoamento de diversos produtos com grande destaque para o algodão, atendendo a demanda da Inglaterra, e principalmente café, cuja produção era uma das maiores da região nordeste e que permaneceu assim mesmo após crise de 1929. A estrada de ferro e seu nó final em Garanhuns foi de extrema importância para a expansão do centro urbano e a consolidação do município como polo regional. Segundo Sette (1956, p. 43):

Como ponta de trilhos, o antigo núcleo de habitações rurais evoluiu depressa, transformando-se em um movimentado entreposto comercial a serviço de numerosos Municípios circunvizinhos e dos arredores, situados tanto em território pernambucano, como nos sertões das Alagoas. [...] Em imediata consequência, importantes firmas comerciais vieram ali instalar seus armazéns e depósitos de compra e venda de produtos regionais e mercadorias vindas do Recife. Pequenas fábricas de beneficiamento e aproveitamento de subprodutos do algodão constituíram os primeiros marcos de um movimento industrial.

Nesse sentido, a paisagem da cidade começa a ser radicalmente alterada e passa a dar lugar a uma paisagem urbana adensada com construções mais modernas. Para Sette (1956, p. 45):

0 trem, em poucas palavras, trouxe a função comercial, incrementou a cultura do café em ascensão até a crise de 1929, valorizou a produção de algodão com a instalação de fábricas para o seu beneficiamento e integral aproveitamento, permitiu a chegada de missões protestantes e congregações católicas interessadas na fundação de estabelecimentos de ensino secundário e facilitou a vinda de um número sempre crescente de famílias recifences em busca de uma estação de repouso ou de cura, as quais, no regresso, se encarregavam de alardear a fertilidade do solo, a pureza da água e a excelência do clima.

Garanhuns permaneceu como "ponta de trilhos" 5 por oitenta e três anos quando, em 1970, a ferrovia foi desativada em razão de um maior foco no transporte rodoviário, teoricamente mais barato para o governo. Conforme mostra a Figura 08, em 1950, Garanhuns possuía 101.471 habitantes, nessa época o município já era o terceiro mais populoso de Pernambuco, no entanto, em 1958, os distritos de São João e Brejão foram emancipados e, em 1963, o mesmo aconteceu com Paranatama e Caetés, assim Garanhuns teve sua dimensão territorial drasticamente reduzida e a população caiu para 71.623 habitantes, porém o núcleo urbano continuou em expansão e já nessa época se aproximava dos vales onde estão presentes as nascentes que atualmente são fortemente impactadas.

\footnotetext{
5 Última cidade da linha do trem.
} 
Figura 08. Evolução populacional de Garanhuns entre 1811 e 2013.

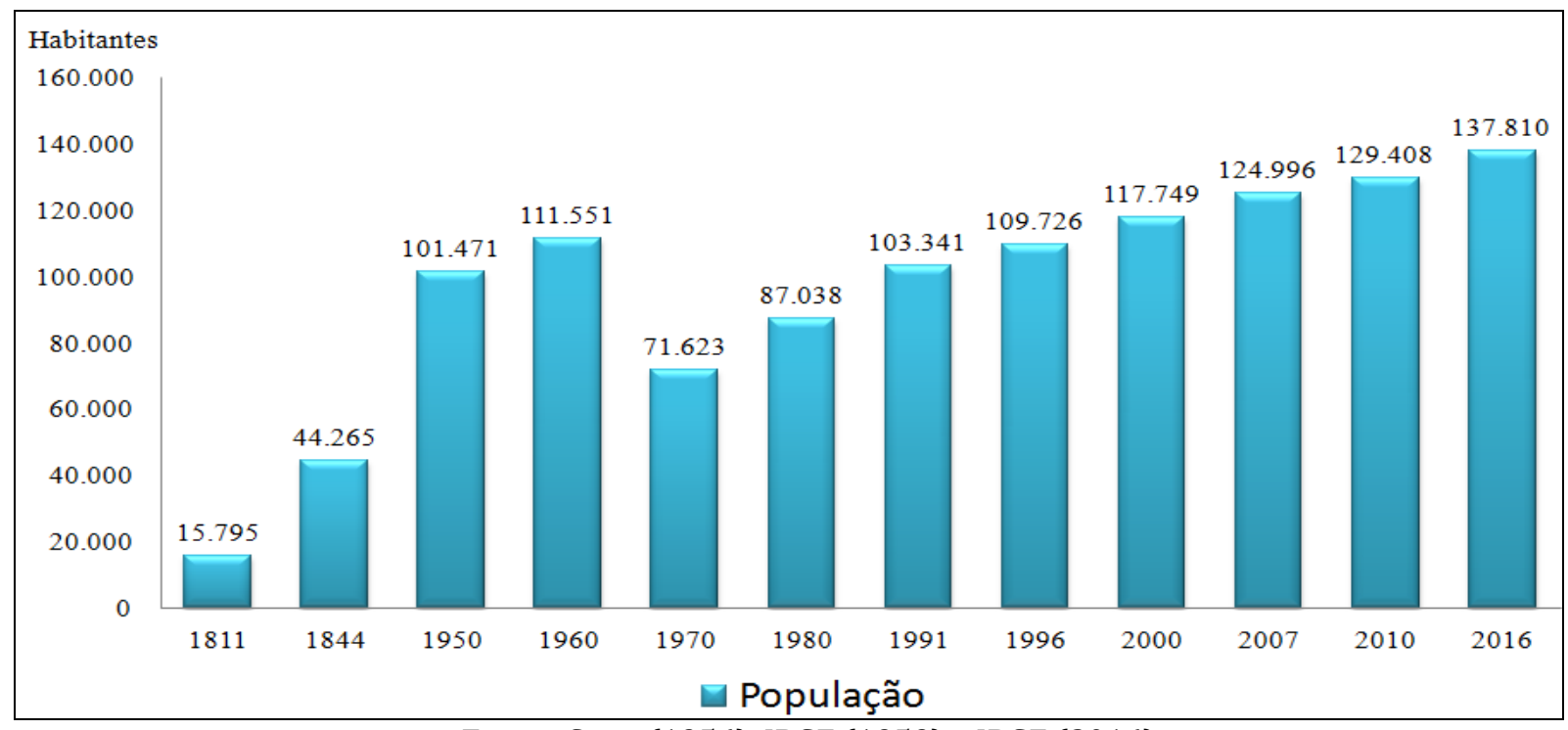

Fonte: Sette (1956), IBGE (1959) e IBGE (2016).

A partir da década de 1970, a taxa de crescimento populacional de Garanhuns manteve-se entre 1 e 2\% ao ano, resultando que, de 1970 até 2016, a população de Garanhuns quase dobrou, aumentando em 66.187 habitantes, crescimento suficiente para que progressivamente a periferia do tecido urbano fosse avançando sobre os vales e as vertentes dos mesmos. Esse avanço também ocorreu em áreas de nascentes, resultando em aterramento das mesmas para a construção de residências, assim como na contaminação e descaracterização de áreas não completamente aterradas, isso ocorreu porque de 1965 até 2016 o núcleo urbano aumentou 17,39 km², ou seja, quase setuplicou em área, passando de aproximadamente $3,72 \mathrm{~km}^{2}$, em 1965, para $21,12 \mathrm{~km}^{2}$ atualmente.

A Figura 09 mostra a expansão do núcleo urbano de Garanhuns entre os anos de 1811 e 2016. Vê-se que inicialmente a então vila era muito pequena e estava distante da maioria dos vales e das nascentes, o que, aliado ao modo simples como se vivia na época, pouco trazia impacto para as nascentes que tinham suas águas captadas e transportadas em lombo de animais essencialmente para uso doméstico. Em 1965, a mancha urbana já havia envolvido as nascentes Vila Maria e Pau Pombo e estava muito próxima da nascente Pau Amarelo, essas eram fontes usadas para abastecimento urbano através de água encanada desde a década de 1920, no caso da nascente Pau Pombo, e de 1930 no caso das demais. Assim, além do impacto da instalação de infraestruturas de captação de água, havia o uso mais intenso por uma população muito maior, o que também já gerava suspeitas de impactos na qualidade da água, uma vez que as residências próximas não possuíam destinação adequada de esgoto doméstico, sendo justamente esse um dos fatores que levaram à descontinuação do abastecimento pelas nascentes no início da década de 1970. Em 1982, após dezessete anos, a mancha urbana cresceu 5,24 km² e já impactava cinco das principais nascentes da cidade. Segundo moradores entrevistados, foi nessa época que inúmeras nascentes foram aterradas e a degradação da qualidade da água 
aumentou com a intensificação do lançamento de esgoto nos vales. No período de 1982 a 2016, o tecido urbano mais que duplicou em área, expandindo-se $12,16 \mathrm{~km}^{2}$ gerando graves problemas ambientais, assim como intensificando os já existentes, tais como reativação, criação e ampliação de voçorocas, lançamentos de esgoto, lixo de construção civil e lixo doméstico em áreas de nascentes.

Figura 09. Expansão urbana de Garanhuns entre 1811 e 2016.

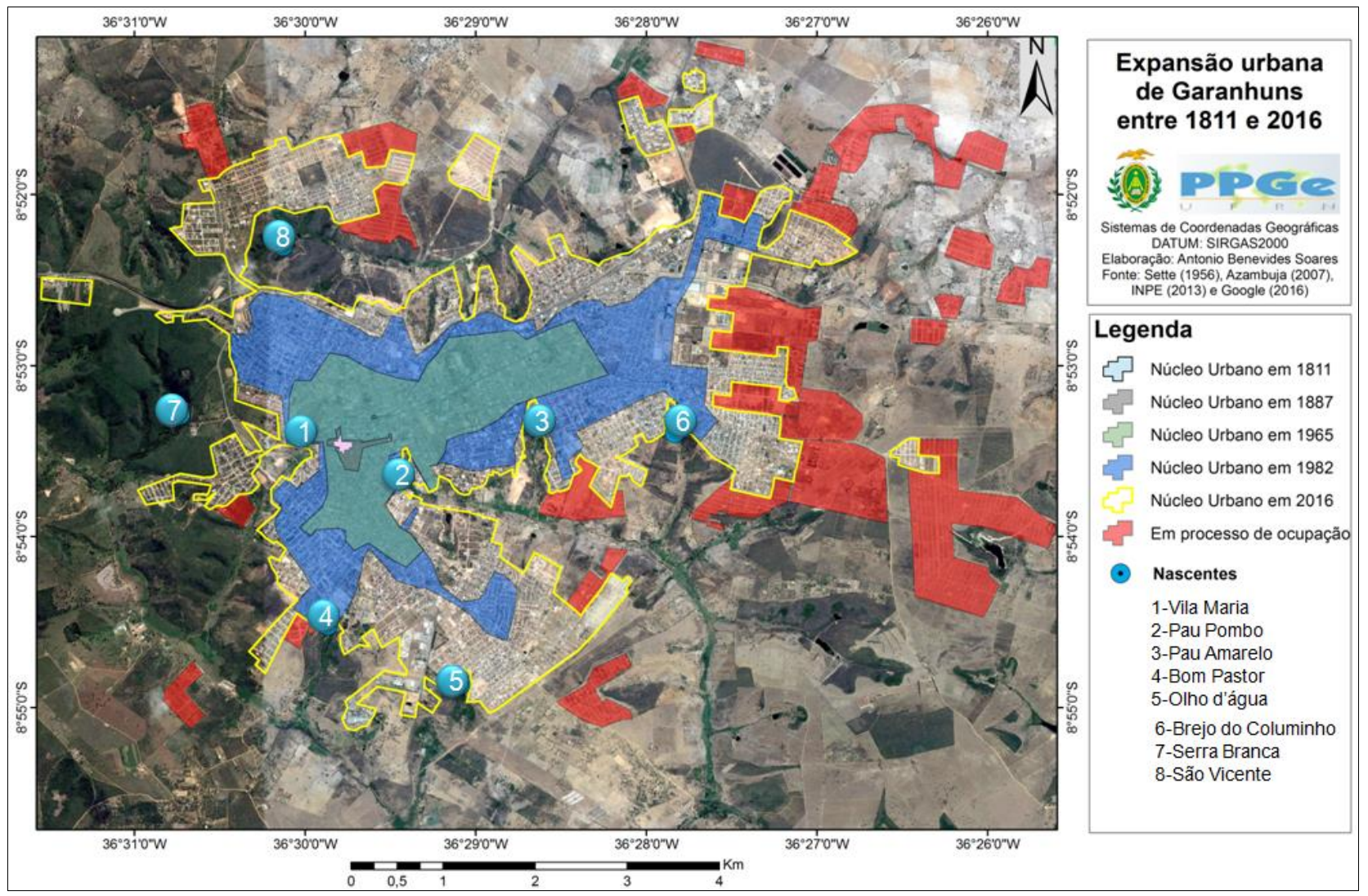

Fonte: Elaborado a partir de dados de Sette (1956), Azambuja (2007), INPE (2013), Google Earth (2016) e pesquisa de campo.

Conforme mostra a Figura 09, a tendência para o futuro é de contínua expansão, pois já existem várias áreas em processo de ocupação, muitas delas com condomínios de alto padrão, outras através de residências do Programa Minha Casa Minha Vida e a grande maioria de loteamentos simples e pequenas invasões. Vários desses condomínios e loteamentos em implantação estão descumprindo o Plano Diretor quanto a aspectos urbanísticos e ambientais, mas mesmo tendo várias deficiências nos projetos, acabam sendo aprovados e tornam-se potenciais degradadores ambientais, já que destinam os esgotos para riachos e áreas de nascentes, o que em alguns casos pode gerar grandes voçorocas, uma vez que os projetos preveem o mesmo tipo de destinação de águas pluviais que já causou várias voçorocas no município.

No Conselho de Defesa do Meio Ambiente do município é comum projetos que desrespeitam a legislação serem submetidos à apreciação da câmara técnica e serem reprovados, mas mesmo assim a execução da obra ocorre. Em vários casos o licenciamento da obra só é feito quando a mesma já está 
concluída, somente como uma burocracia para obter a documentação do imóvel, ignorando a importância dos parâmetros ambientais sem que isso acarrete em punição. Assim, o que se verifica em Garanhuns é que a expansão urbana ocorre majoritariamente de forma não planejada com frequência desrespeitando a legislação e os aspectos ambientais fundamentais, tal como a declividade das encostas e as áreas de nascentes. Essa não é uma lógica recente no município, porém atualmente se mostra ainda mais grave uma vez que existem inúmeros aparatos legais que estão sendo ignorados, principalmente a Lei $\mathrm{n}^{\circ} 3620 / 2008$, que instituiu o Plano Diretor de Garanhuns, todavia, no passado também foram ignoradas a Lei no. 1.831, de 1978, referente ao Plano de Desenvolvimento Urbano e a Lei no 2992/2000 de Uso e Ocupação do Solo, que possuíam aparatos legais de proteção das nascentes que não foram respeitados.

Ao longo da história, Garanhuns apresentou dois grandes momentos de expansão urbana que tiveram ligação com momentos de dinamização da economia do município. 0 primeiro momento fundamental foi a implantação da linha férrea, em 1887, que ligava Garanhuns ao Recife. Já o segundo momento, se inicia em 2005, com a chegada Universidade Federal Rural de Pernambuco (UFRPE), através da Unidade Acadêmica de Garanhuns (UAG), com vários cursos cuja escolha "[...] foi feita tendo em vista as características do entorno da UAG, levando em consideração que o papel central da universidade é de influir no desenvolvimento regional” (UFRPE, 2014).

Após a vinda da UFRPE-UAG, várias universidades que oferecem cursos a distância também chegaram e as universidades já existentes passaram por ampliação e criação de novos cursos, assim, atualmente, o município se configura como polo universitário, uma vez que possui várias instituições que oferecem cursos presenciais e a distância, tanto em nível superior como técnico, ambos muito procurados por moradores da região que antes só tinham acesso a cursos como direito, medicina, engenharia e ciência da computação em capitais. Diante desse cenário, um grande contingente de pessoas passou a demandar moradia e serviços na cidade, assim como aumentou o fluxo de estudantes de outros municípios não só de Pernambuco, mas de outros estados. Nesse contexto o preço do solo encareceu progressivamente e o município experimenta um forte crescimento imobiliário com a construção de condomínios populares e de luxo na periferia da cidade. Mais recentemente, a vinda de empreendimentos empresariais onde um shopping é o maior destaque vem reforçando essa lógica de valorização do espaço e contribuindo para uma rápida expansão urbana, gerando assim pressão sobre as áreas ambientalmente frágeis do município, que tem seu crescimento limitado pelos vales onde se localizam as nascentes alvo do presente estudo. É importante destacar que além da expansão horizontal também ocorre a verticalização das moradias, o que também traz sérias consequências para as nascentes, pois, cerca de $88 \%$ do esgoto do município é lançado sem qualquer tratamento nos vales onde as nascentes se localizam. 


\subsubsection{Implicações ambientais da expansão urbana nas nascentes}

Diante das características do processo de expansão urbana do município, os danos ambientais nas nascentes são evidentes e a cada dia ameaçam mais a qualidade e até mesmo a existência desses mananciais. Com exceção da nascente Serra Branca que ainda está relativamente distante e muito bem protegida, pois tem sua água comercializada, todas as nascentes mostradas no mapa da Figura 09 possuem, apesar de algumas variações, contextos socioambientais gravíssimos que evidenciam impactos cumulativos de mais de um século.

Nas nascentes Pau Amarelo, Pau Pombo e Vila Maria, por exemplo, esses contextos são similares, gravíssimos e simbólicos, pois todas as três foram utilizadas para abastecimento urbano por água encanada até a década de 1970 e ainda hoje formam riachos importantes para os açudes que abastecem a cidade, no entanto todas sofrem com ocupações nas encostas onde também ocorre a supressão da vegetação, modificação e exposição do solo a processos de erosão linear que apresentam vários estágios e inclusive voçorocamentos que trazem riscos a dezenas de habitações próximas. Devido a expansão urbana ocorrer sem a implantação adequada de saneamento, uma vez que apenas $12 \%$ do esgoto urbano é coletado, as áreas de exfiltração das nascentes sofrem contínuo impacto por lançamento de esgotos que são ligados nos canais de águas pluviais o que além de contaminar a água gera, em períodos de chuva, uma grande vazão que altera completamente as áreas de exfiltração das nascentes.

Como as problemáticas e implicações socioambientais apresentam significativa semelhança entre as nascentes e a intenção deste trabalho não é fazer análise profunda dessas problemáticas daremos maior destaque a nascente Vila Maria e em seguida destacaremos algumas implicações e impactos do processo de expansão urbana em algumas nascentes presentes no meio urbano.

A nascente Vila Maria (Fig. 10) fez parte, entre as décadas de 1930 e 1970, do sistema de abastecimento público municipal por água encanada. No entanto, a captação foi interrompida devido às suspeitas de contaminação por esgoto. Desde então, a situação se agravou progressivamente e o processo de ocupação no entorno da nascente revela um contexto contínuo de impacto de esgoto e as áreas de recarga e de exfiltração já se encontram parcialmente descaracterizadas por uma voçoroca com trezentos metros de comprimento, chegando a pouco mais de sete metros de profundidade. Como esse processo erosivo é causado por um canal de águas pluviais que tem ligações de esgoto doméstico, além do grave processo erosivo, há também uma alta probabilidade de contaminação da água da nascente tanto diretamente na área de exfiltração como pelo contato com o lençol freático, pois o aprofundamento contínuo da voçoroca facilita o acesso do esgoto ao nível freático.

No período de 2007 a 2014, o entorno do vale onde a nascente Vila Maria se localiza sofreu um amplo processo de ocupação e a tendência para o futuro é intensificação desse crescimento, já existindo áreas de encosta aterradas para tal fim (Fig. 10). Nas vertentes do vale onde a nascente se 
localiza, há várias ocupações em APP de encosta, uma vez que foram construídas em encostas com inclinação acima de 45ㅜㅡ, assim são ocupações que oferecem risco para seus moradores e impactam a drenagem da microbacia da nascente, causando aumento da velocidade do escoamento superficial, redução da infiltração e, consequentemente, interferência na recarga do lençol freático que abastece a nascente.

Figura 10. Contexto socioambiental da Nascente Vila Maria.

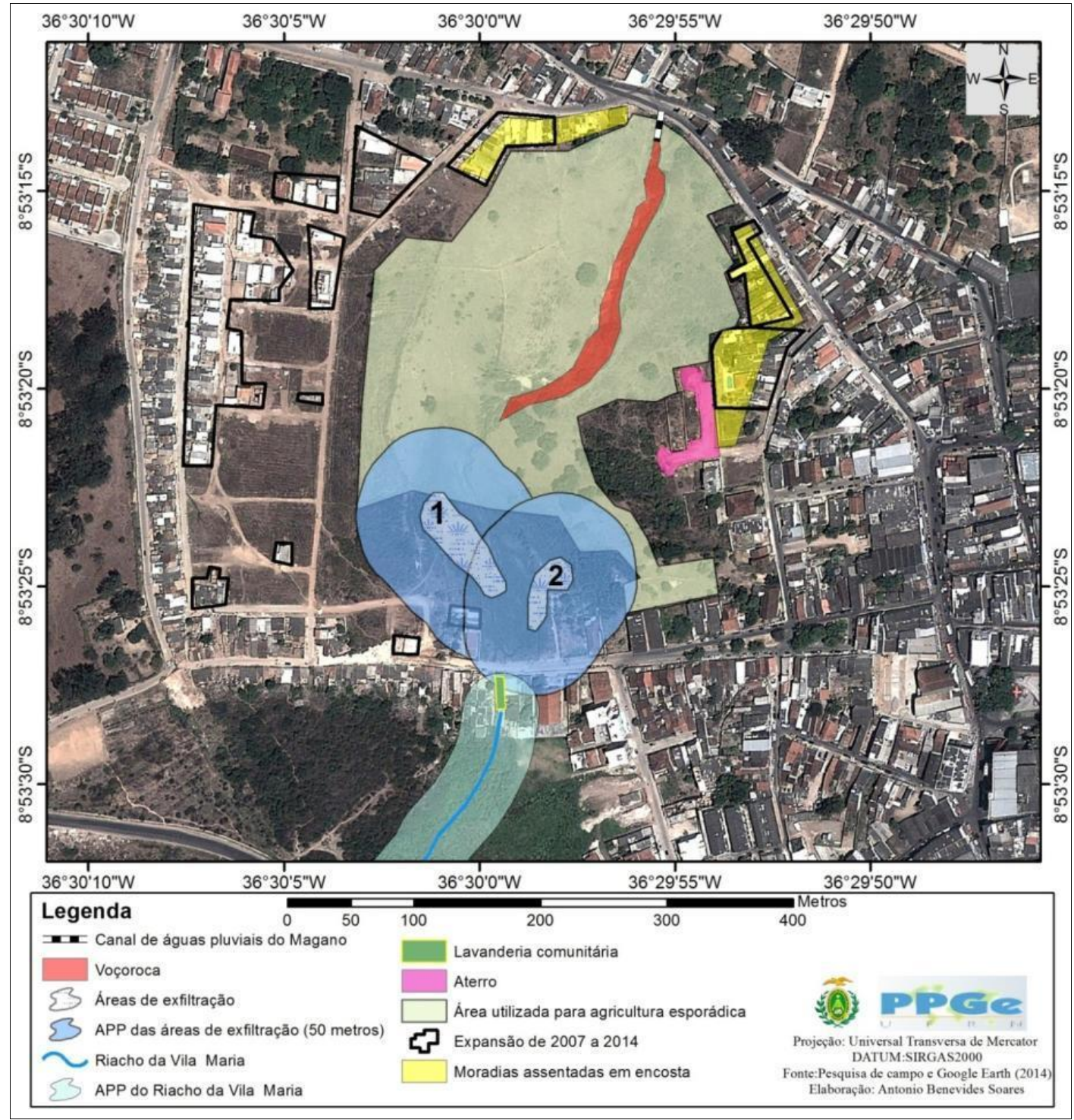

Fonte: Elaborado com base na pesquisa de campo e (Google, 2014).

Dentro do raio de proteção da APP da nascente ocorre o uso do solo para agricultura esporádica, para a criação de animais e construção de edificações, assim a APP da nascente recebe impacto por esgoto e lixo das habitações existentes bem como do pisoteio dos animais e das pessoas que utilizam a água proveniente da nascente na lavanderia comunitária e até mesmo para afazeres 
domésticos (Fig. 10). Nesse sentido, verificam-se impactos nocivos não somente à nascente, como também à saúde dos usuários da água proveniente da mesma e do córrego originado por ela.

A nascente Pau Amarelo (Fig.11) foi usada desde a década de 1930 até os 1970, para o abastecimento de água da cidade, atualmente, em razão da expansão urbana, apresenta-se totalmente impactada por um contexto de impactos que envolve aterramentos nas encostas do vale onde a nascente se localiza, lançamento de esgoto e de lixo doméstico e de construção civil. Também há inúmeras ocupações em áreas que além de trazer risco aos moradores alteram a drenagem das encostas do vale favorecendo o surgimento e a ampliação dos processos erosivos já existentes e assim aterrando os veios de exfiltração da nascente bem como contaminando a água com o esgoto despejado in natura.

Figura 11. Processos erosivos em área aterrada com lixo de construção civil no vale onde a Nascente Pau Amarelo se localiza.

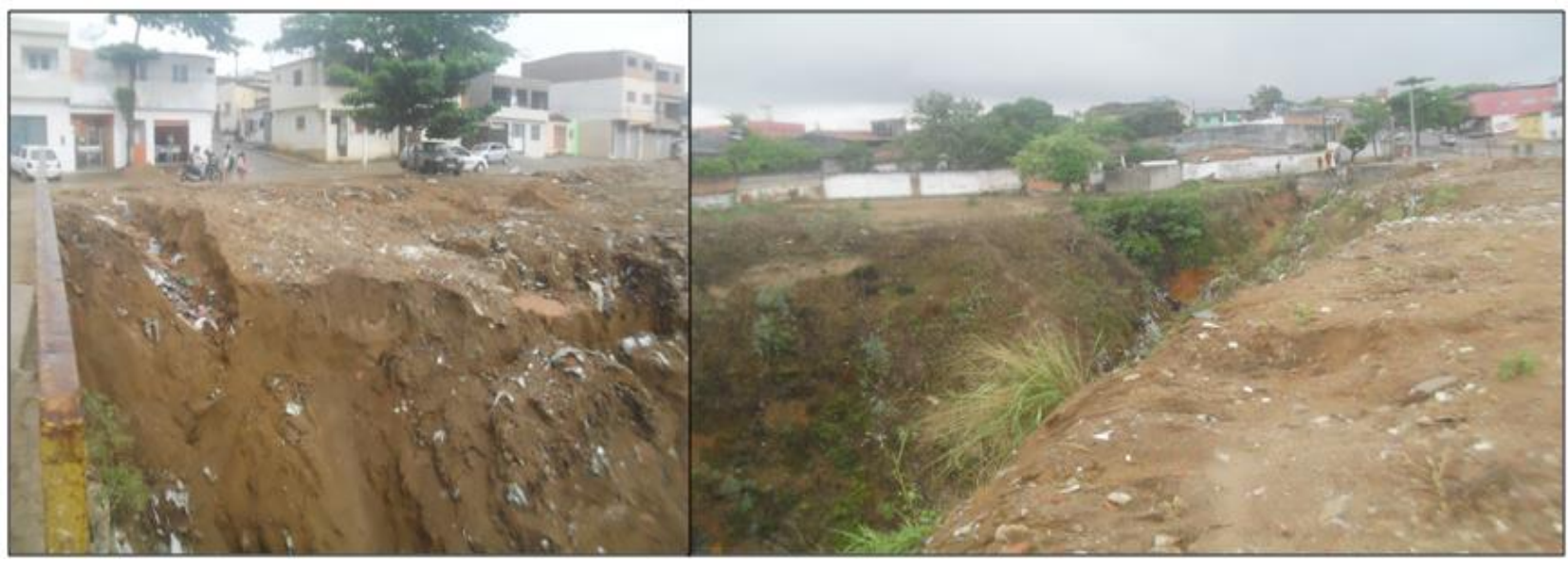

Fonte: Acervo do autor (2015).

A nascente Bom Pastor localiza-se em um fundo de vale a sudoeste do centro urbano, em propriedade pertencente à Universidade Federal Rural de Pernambuco (UFRPE). As vertentes do vale onde a nascente se localiza possuem diversos processos erosivos tendo como destaque uma expressiva voçoroca surgida em razão da existência de um canal que concentra os fluxos de águas pluviais juntamente com esgoto (Fig. 12). Assim, quando chove, a APP da nascente recebe grande quantidade de sedimentos carreados pela enxurrada, impactando a área de exfiltração e o riacho originado na mesma. 
Figura 12. Voçoroca causada pela destinação de águas pluviais juntamente com esgoto no entorno da nascente Bom Pastor.

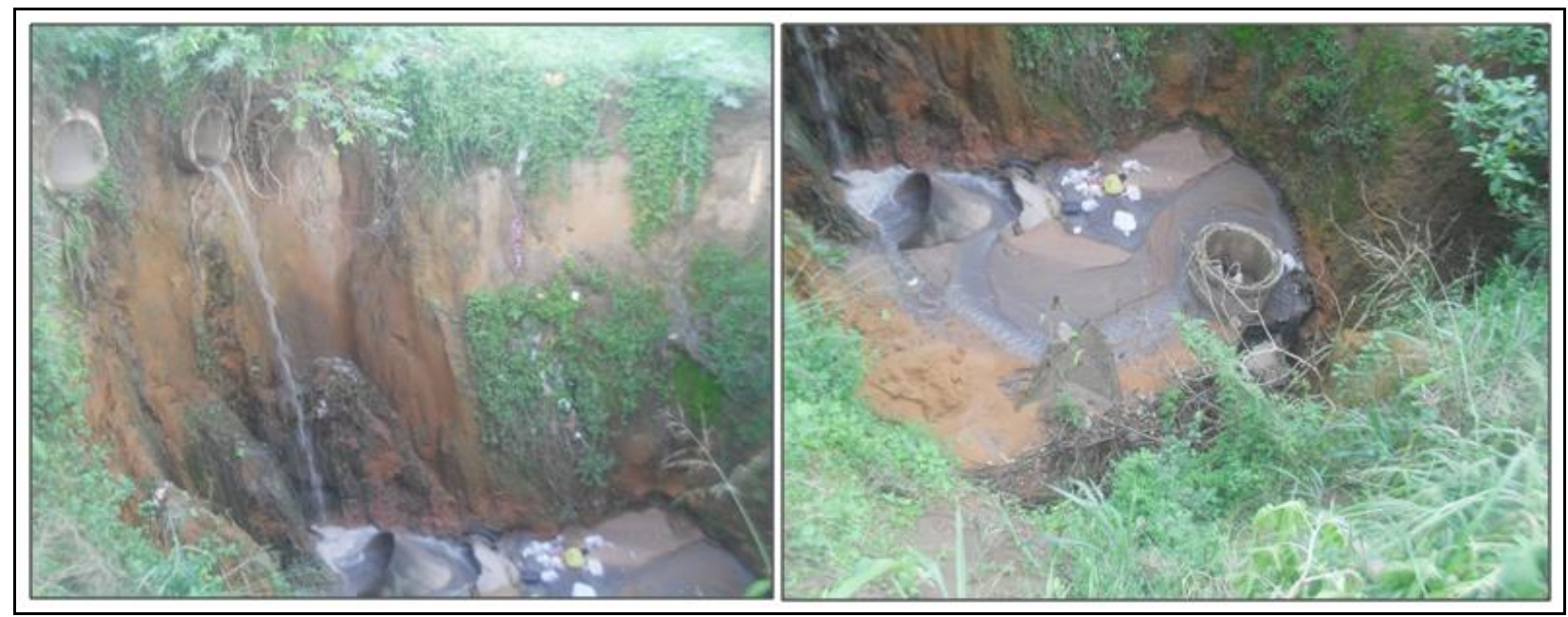

Fonte: Acervo do autor (2015).

A nascente Olho d'Água localiza-se ao sul do centro urbano de Garanhuns no fundo do vale de uma propriedade particular. A propriedade onde a nascente se localiza é cercada e engloba o vale onde ocorre a exfiltração por isso apesar de haver contato com a zona urbana, dentro dos limites da propriedade, a cobertura vegetal encontra-se protegida, sendo uma das raras existentes no município que pode ser considerada como verdadeiro resquício de mata atlântica, possuindo vários exemplares de alto porte. No entanto, assim como as anteriores, a nascente Olho d'Água foi impactada por canalização inadequada de águas pluviais resultando numa voçoroca com aproximadamente 170 metros de comprimento e que passa dos 5 metros de profundidade, alcançando a camada impermeável sobre a qual o lençol freático se assenta. Nessa voçoroca, ocorre descarte de lixo doméstico e quando chove o lixo é carreado para a APP da nascente (Fig. 13).

Figura 13. A: Área da principal surgência da Nascente Olho d'Água; B: Voçoroca causada por águas pluviais canalizadas juntamente com esgoto.

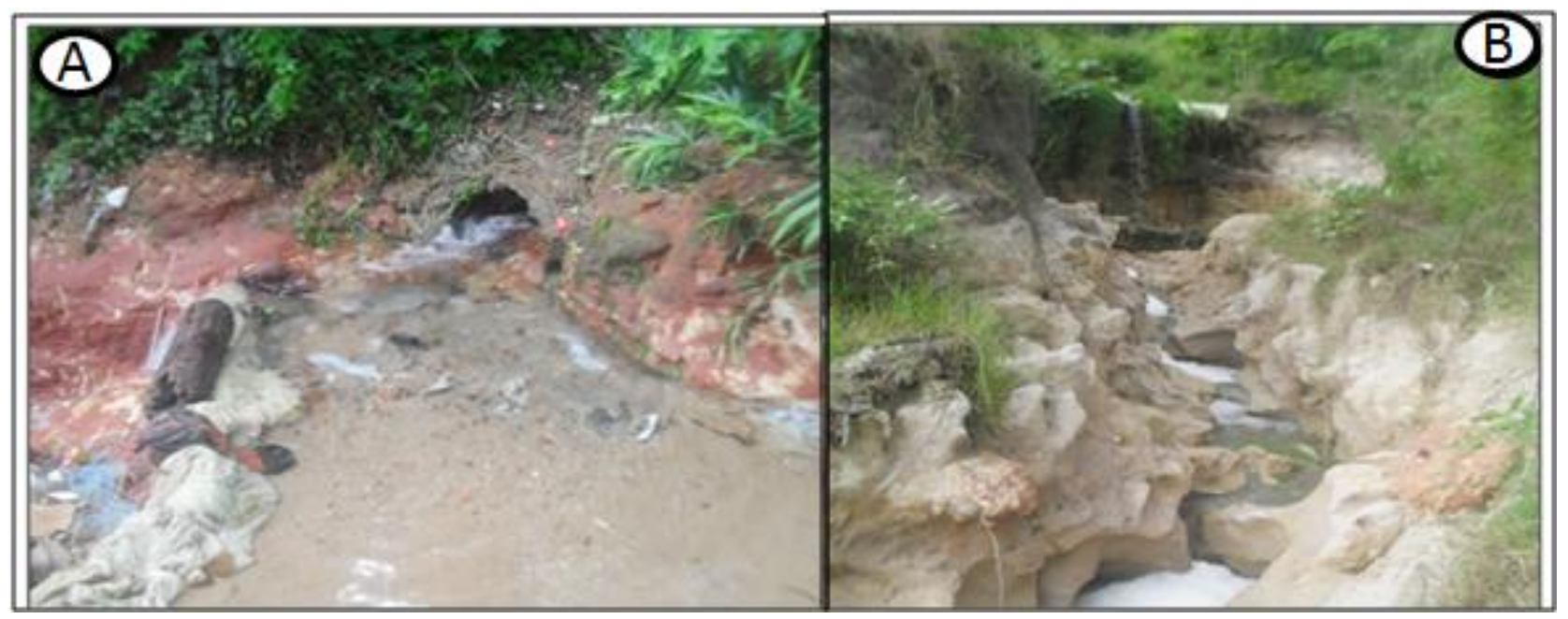

Fonte: Acervo do autor (2015). 


\section{CONCLUSÕES}

A elaboração deste artigo partiu da constatação da existência de graves problemáticas originadas no processo de expansão do espaço urbano de Garanhuns e por isso objetivou analisar tais problemáticas caracterizando a expansão urbana entre o período de 1811 e 2016.

Ao caracterizar a área de estudo em seus aspectos físicos, verificou-se que as características ambientais do município são determinantes para a existência das nascentes presentes no meio urbano, pois as particularidades geológicas são favoráveis ao armazenamento da água infiltrada em solos com boa permeabilidade e os aquíferos são abastecidos em três meses de grande excedente hídrico que ocorre em função de chuvas orográficas relativas à localização da área de estudo e as elevadas altitudes na faixa de rebordo do Planalto da Borborema, o que também é fundamental para a predominância de brejos de altitude no município. As características favoráveis ao surgimento e alimentação deram a Garanhuns importantes nascentes e o destaque como a cabeceira de uma vasta rede hídrica que inclui as nascentes do Rio Mundaú, rio que envolve dois estados e possui grande importância para a região. Assim, as nascentes existentes devem ganhar destaque no contexto da bacia em razão de sua relevância regional. Nos aspectos físicos também verificou-se que o relevo e os solos existentes no núcleo urbano tornam as vertentes dos vales onde as nascentes se localizam susceptíveis à ocorrência de processos erosivos que são progressivamente intensificados pela ocupação inadequada do solo, redundando em voçorocas e impactos nas nascentes.

No tocante à expansão do núcleo urbano, verificou-se que em razão da facilidade na obtenção de água as nascentes tiveram grande influência no estabelecimento do núcleo urbano inicial. Posteriormente, a chegada da linha férrea promoveu vigorosa dinamização da economia, derivando em rápido crescimento urbano que acabou por impactar as nascentes, pois resultou em demanda por água canalizada, e na medida em que o núcleo urbano avançava, os esgotos das residências impactavam a qualidade das águas das nascentes usadas no abastecimento, sendo essa uma das razões do abandono das nascentes para abastecimento urbano após quarenta anos de uso. No momento atual de dinamização da economia, promovida pela emergência do polo universitário, o impacto nas nascentes continua se intensificando com o lançamento de esgotos, aterramentos e contínua degradação e/ou impermeabilização das áreas de recarga, com grave tendência de piora em razão de grandes áreas em expansão no entorno de todo o núcleo urbano, as quais ignoram as peculiaridades ambientais e, em sua maior parte, também as normas legais. 


\section{AGRADECIMENTOS}

Os autores deste trabalho agradecem ao Programa de Pós-Graduação em Geografia da UFRN e a Coordenação de Aperfeiçoamento de Pessoal de Nível Superior pelo apoio ao estudo.

\section{REFERÊNCIAS}

AB'SABER, A. N. Os sertões: a originalidade da terra. Ciência Hoje. Rio de Janeiro, v. 3, n.18, mai/jun, 1985.

ANDRADE, André Ricardo S. et al. Estudo do comportamento de períodos secos e chuvosos no município Garanhuns, PE, para fins de planejamento agrícola. Pesquisa Aplicada \& Agrotecnologia, v.1 n.1, p. 55-61, 2008.

AZAMBUJA, Nunes Renata. Análise geomorfológica em áreas de expansão urbana no município de Garanhuns-PE. Dissertação (Mestrado em Geografia) - Universidade Federal de Pernambuco,Recife. 2007.

CPRM-Companhia de Pesquisa de Recursos Minerais. Geobank. Disponível em: <http://www.cprm.gov.br/>. Acesso em: $10 \mathrm{de}$ ago. 2013.

CONDEPE/FIDEM. Projeto Todos Por Pernambuco. Agência Estadual de Planejamento e Pesquisas de Pernambuco, Recife, 2010. Disponível em: <http://www2.condepefidem.pe.gov.br>. Acesso em: 10 jul. 2014.

CORREA, A. C. B. ; TAVARES, B. DE A. C. ; MONTEIRO, K. A.; Cavalcanti, L. C. S. ; LIRA, D. R. Megageomorfologia e morfoestrutura do planalto da borborema. Revista do Instituto Geológico, v. 31, p. 35-52, 2010.

DIAS, João de Deus Oliveira. A terra dos Garanhuns. Garanhuns: PE: Jornal Monitor, 1954. EMBRAPA, Empresa Brasileira de Pesquisa Agropecuária. Levantamento de reconhecimento de baixa e média intensidade dos solos do Estado de Pernambuco. Rio de Janeiro: Embrapa Solos, 2000. (Embrapa Solos, Boletim de Pesquisa; 11).

GARANHUNS. Plano Diretor Participativo do Município de Garanhuns-PE. Lei n 3620 de 2008. Secretaria Planejamento.Garanhuns: 2008.

GOOGLE. Software Google Earth, 2013. . Software Google Earth, 2016

IBGE, Instituto Brasileiro de Geografia e Estatística. Garanhuns. Disponível em https://cidades.ibge.gov.br/v4/brasil/pe/garan huns/panorama Acesso em: 25 abr. 2016.
. Monografia de Garanhuns. Rio de Janeiro: Serviço Gráfico do IBGE, 1959.

. Censo 2010: população do Brasil é de 190.732.694 pessoas. Disponível em <http://censo2010.ibge.gov.br/noticiascenso?view $=$ noticia\&id $=1$ \&idnoticia $=1766 \& \mathrm{t}=$ ce nso-2010-populacao-brasil-190-732-694pessoas >. Acesso em: 25 abr. 2013.

. Mapeamento Sistemático. Disponível em: <ftp://geoftp.ibge.gov.br/mapeamento sistemat ico $>$. Acesso em: 20 out. 2013.

. Garanhuns, IBGE cidades. Disponível em < http://www.cidades.ibge.gov.br/xtras/perfil.ph p?lang $=\&$ codmun $=260600 \&$ search $=\|$ infogr $\% E 1$ ficos:-informa $\%$ E7\%F5es-completas $>$. Acesso em: 10 de agosto de 2013.

INPE, Instituto Brasileiro de Pesquisas Espaciais. TOPODATA. Disponível em: < http://www.dsr.inpe.br/topodata/>. Acesso em: 10 ago. 2013.

JATOBÁ, L. Clima. In: ANDRADE, Manuel Correia de Oliveira (Org.). Atlas Escolar Pernambuco. 2. ed. João Pessoa: Grafset,2004.

JORNAL DO TEMPO. Totais Pluviométricos e temperaturas mínimas e máximas mensaispara Garanhuns-PE. Disponível em:< http://jornaldotempo.uol.com.br/climatologia.h tml/Garanhuns-PE.>. Acesso em: 30 de nov. 2014.

LINS, R. C. As áreas de exceção do Agreste de Pernambuco. Recife: SUDENE/PSU/SER, 1989. (Série Estudos Regionais).

PERNAMBUCO. Plano Diretor de Recursos Hídricos da Bacia do Rio Mundaú. Secretaria de Recursos Hídricos. Recife, 1999.

. Plano estadual de recursos hídricos:

Documento Síntese. Secretaria de Recursos

Hídricos, PROÁGUA Semi-Árido, Ministério do Meio Ambiente - Secretaria de Recursos Hídricos, Recife-PE, 1998.

PNUD-Programa das Nações Unidas para o Desenvolvimento. Garanhuns-PE. Disponível em< 
http://www.atlasbrasil.org.br/2013/pt/perfil_m /garanhuns_pe>. Acesso em: 20 de agosto 2014.

PORTO, K. C.; CABRAL, J. J. P.; TABARELLI, M. (Org.). Brejos de altitude em Pernambuco e Paraíba: história natural, ecologia e conservação. Ministério do Meio Ambiente, Brasília, 2004. (Série Biodiversidade, 9).

SENTELHAS, P. C.; ANGELOCCI, L. R. Exemplo do Balanço Hídrico Climatológico Normal, Garanhuns-PE. Escola Superior de Agricultura Luiz de Queiroz da Universidade de São Paulo, 2009. Disponível em:

<http://www.lce.esalq.usp.br/aulas/lce306/Aul a9.pdf>. Acesso em: 10 jan. 2014.

SETTE, Hilton. Origem e evolução urbana de Garanhuns. Boletim carioca de Geografia, n. 9. Rio de Janeiro, 1956.

UFRPE. Universidade Federal Rural de Pernambuco. UFRPE celebra 9 anos da Unidade Acadêmica de Garanhuns (UAG) nesta sexta (05/09). Disponível em:

<http://www.ufrpe.br/noticia_ver.php?idConte udo=14436>. Acesso em: 12 ago. 2014. 